\title{
ANTIOXIDANT STUDIES OF ONE AYURVEDIC MEDICINE ASWAGANDHARISHTAM
}

\author{
KOTTESWARI M" ${ }^{1}$, MUDIGANTI RAM KRISHNA RAO ${ }^{2 *}$, PRABHU K ${ }^{3}$, SIVA KUMAR ${ }^{4}$, SAMPAD SHIL ${ }^{2}$
}

${ }^{1}$ Department of Anatomy, Madha Dental College, Chennai, Tamil Nadu, India. ${ }^{2}$ Department of Industrial Biotechnology, Bharath Institute of Higher Education and Research, Chennai, Tamil Nadu, India. ${ }^{3}$ Department of Anatomy, Sree Balaji Medical College and Hospital, Chennai.

Tamil Nadu, India. ${ }^{4}$ Department of Oral Pathology, Madha Dental College, Chennai, Tamil Nadu, India. Email: mrkrao1455@gmail.com

Received: 29 May 2018, Revised and Accepted: 06 July 2018

ABSTRACT

Objective: The present study deals with the antioxidant study of one Ayurvedic medicine Aswagandhrishtam by three different methods, namely reducing power, 2,2-diphenyl-1-picrylhydrazyl (DPPH), and 2,2'-azino-bis(3-ethylbenzothiazoline-6-sulfonic acid (ABTS) assays.

Methods: Aswagandharishtam, which is a liquid medicine, was taken as such at various concentrations for all the three assays.

Results: The results show that Aswagandharistam has good antioxidant potential when compared with ascorbic acid as standard. The IC ${ }_{50}$ values of reducing power assay were 250.142, that of DPPH were 103.607, and of ABTS assay were 197.79 as compared with that of ascorbic acid being 19.59 .

Conclusion: All the three assays indicated that Aswagandharishtam showed very good antioxidant results.

Keywords: Aswagandharishtam, 2,2'-Azino-bis(3-ethylbenzothiazoline-6-sulfonic acid, 2, 2-Diphenyl-1-picrylhydrazyl, Vata, Antioxidant, Epilepsy, Ascorbic acid.

(C) 2018 The Authors. Published by Innovare Academic Sciences Pvt Ltd. This is an open access article under the CC BY license (http://creativecommons. org/licenses/by/4. 0/) DOI: http://dx.doi.org/10.22159/ajpcr.2018.v11i11.27593

\section{INTRODUCTION}

The evaluation of the scientific efficacy of Ayurvedic and Siddha drugs has become an urgent necessity for their acceptance and promotion. Although these systems are in vogue since ages, the scientific validation with modern parameters will prove their efficacy and help in resurrecting these age-old systems of medicine. This is all the more required due to the development of multidrug-resistant pathogens and increase in the incidence of dreaded diseases such as cancer, malaria, and AIDS, with which the modern medicine is unable to cope up with. It will be wise to develop a safe, cost-effective medicine which could have less or no side effects. For the past two decades, increasing focus is being given by government and private players in this direction [1-30]. Ministry of AYUSH, Government of India, and other such organizations should come forth to develop techniques, protocols, and methods to establish the Ayurvedic and Siddha medicines at the global level.

The present study is one step in this direction. The study deals with the antioxidant study of Ashwagandharishtam or Aswagandharishtam, which is a liquid Ayurvedic medicine used in psychiatric conditions, dullness, loss of memory, sluggishness, epilepsy, low digestion power, piles, and diseases caused by Vata imbalance. It is also used as nerve tonic, for sexual disorders and for depression. Being an Arishta, it contains about 5-10\% of self-generated natural alcohol which helps in the delivery of the drug in the body. The dosage of this medicine is usually $12-24 \mathrm{ml}$ twice daily after food or as advised by the physician.

The present work undertakes the antioxidant assay study of this medicine to understand its possible mechanism of action. The manufactures of this medicine are Baidyanath, Dabur, AVN, AVP, Vaidik Herbs, and Kottakkal Arya Vaidya Sala.

Since this medicine helps in rejuvenation of mind and body, its role as an antioxidant should be understood. The present study encompasses three antioxidant assays, namely reducing power assay, 2,2-diphenyl-1picrylhydrazyl (DPPH) assay, and 2,2'-azino-bis(3ethylbenzothiazolin6sulfonic acid (ABTS) assay.

\section{METHODS}

This Arishtam is made of the following ingredients which are divided into two sections: Kwatha dravyas (Main components) and Prakshepa dravyas (additive components).

The coarse powder of Kwatha dravyas (Main components) is added with water, boiled and reduced to $12.288 \mathrm{~L}$, and filtered. It is added with honey, and Prakshepa Dravya (additive components) powders are added and kept in an airtight container for 1 month for fermentation. After a month time, it is filtered and preserved.

Aswagandharishtam ingredients:

Kwatha dravyas (main components)

Ashwagandha (Withania somnifera) - Root - $2.4 \mathrm{~kg}$

Mushali (Chlorophytum tuberosum) - Root - $960 \mathrm{~g}$

Manjishta (Rubia cordifolia) - Root - $480 \mathrm{~g}$

Haritaki (Terminalia chebula) - Fruit - $480 \mathrm{~g}$

Nisha - Turmeric - (Curcuma longa) rhizome - $480 \mathrm{~g}$

Daruharidra (Berberis aristata) - Stem - $480 \mathrm{~g}$

Yashtimadhu - Licorice - (Glycyrrhiza glabra) Root - $480 \mathrm{~g}$

Rasna (Pluchea lanceolata) - Root/leaf - $480 \mathrm{~g}$

Vidari (Pueraria tuberosa) - Root - $480 \mathrm{~g}$

Arjuna (Terminalia arjuna) - stem bark - $480 \mathrm{~g}$

Mustaka (Cyperus rotundus) - Rhizome - $480 \mathrm{~g}$

Trivrit (Ipomoea turpethum) - Root - $480 \mathrm{~g}$

Sariva (Indian sarsaparilla - Hemidesmus indicus) - Root - $384 \mathrm{~g}$

Krishna Sariva (Cryptolepis buchanani) - Root - $384 \mathrm{~g}$

Shweta Candana (Santalum album) - heartwood - $384 \mathrm{~g}$

Rakta Candana (Pterocarpus santalinus) - heartwood - $384 \mathrm{~g}$

Vacha (Acorus calamus) - Rhizome - $384 \mathrm{~g}$

Chitraka (Plumbago zeylanica) - Root - $384 \mathrm{~g}$

Water for decoction - $98.304 \mathrm{~L}$

Boiled and reduced to $12.288 \mathrm{~L}$

Madhu - Honey - $14.4 \mathrm{~kg}$

Prakshepa - Dravyas (additive components)

Dhataki - Woodfordia fruticosa - Flower - $768 \mathrm{~g}$ 
Shunti - Ginger - (Zingiber officinale) - Rhizome - $96 \mathrm{~g}$

Maricha - Pepper - (Piper nigrum) - Fruit - $96 \mathrm{~g}$

Pippali - Long pepper - (Piper longum) - $96 \mathrm{~g}$

Twak - Cinnamon - (Cinnamomum zeylanicum) - $192 \mathrm{~g}$

Ela - Cardamom - (Elettaria cardamomum) - $192 \mathrm{~g}$

Patra (Cinnamomum tamala) - leaves - $192 \mathrm{~g}$

Priyangu (Callicarpa macrophylla) - Flower - $192 \mathrm{~g}$

Nagakeshara (Mesua ferrea) - Stamen - $96 \mathrm{~g}$

Aswagandharishtam was procured from Standard Ayurvedic Vendors at Chennai.

The drug was subjected to antioxidant assays, namely reducing power, DPPH, and ABTS assays.

\section{Reducing power assay [31]}

Various concentrations of the Aswagangharishtam in $1 \mathrm{ml}$ of 10\% DMSO solution was mixed with phosphate buffer $(2.5 \mathrm{ml})$ and potassium ferricyanide $(2.5 \mathrm{ml})$ and incubated at $50^{\circ} \mathrm{C}$ for $20 \mathrm{~min}$. Aliquots of trichloroacetic acid $(2.5 \mathrm{ml})$ were added to the mixture, which was then centrifuged at $3000 \mathrm{rpm}$ for $10 \mathrm{~min}$. The upper layer of solution $(2.5 \mathrm{ml})$ was mixed with distilled water $(2.5 \mathrm{ml})$ and a freshly prepared ferric chloride solution $(0.5 \mathrm{ml})$. The absorbance was measured at $700 \mathrm{~nm}$. A blank was prepared without adding sample or standard. Ascorbic acid at various concentrations was used as reference standard. Increased absorbance of the reaction mixture indicates an increase in reducing power.

$\%$ inhibition $=$ [Aswagandharishtam-Control/Aswagandharishtam $]$ $\times 100$

\section{DPPH radical scavenging assay [32]}

The method described by Oyedemi and Afolayan et al. (2011) was used to determine the DPPH scavenging activity of the Aswagandharishtam. The solution of $0.135 \mathrm{mM}$ DPPH was prepared in methanol. Different concentrations of the medicine $(0.1 \mathrm{ml})$ were mixed with $1.9 \mathrm{ml}$ of DPPH solution. The reaction mixture was vortexed thoroughly and left in the dark at room temperature for $30 \mathrm{~min}$. The absorbance of the mixture was measured at $517 \mathrm{~nm}$. Ascorbic acid was used as the reference drug. The ability of the medicine to scavenge DPPH radical was calculated from the following formula:

\% DPPH inhibition= [(OD of Control - OD of Aswagandharishtam) $/(\mathrm{OD}$ of Control)] $\times 100$

\section{ABTS radical scavenging assay [33]}

A stock solution of ABTS radical cation was prepared by dissolving ABTS $(7 \mathrm{mM}, 25 \mathrm{ml}$ in deionized water) with potassium persulfate $\left(\mathrm{K}_{2} \mathrm{~S}_{2} \mathrm{O}_{8}\right)(140 \mathrm{mM}, 440 \mu \mathrm{L})$. The mixture was left to stand in the dark at room temperature for 15-16 $\mathrm{h}$ (the time required for the formation of the radical) before use. For the evaluation of ABTS radical scavenging activity, the working solution was prepared by the previous solution and diluting it in ethanol to obtain the absorbency of $0.700 \pm 0.02$ at $734 \mathrm{~nm}$. The solvent extracts and Aswagandharishtam $(0.1 \mathrm{ml})$ at different concentrations were mixed with the ABTS working solution $(1.9 \mathrm{ml})$, and the reaction mixture was allowed to stand at room temperature for 20 min; then, the absorbance was measured using a ultraviolet-visible spectrophotometer at $734 \mathrm{~nm}$. The radical scavenging activity is given as ABTS radical scavenging effect that is calculated by the following equation:

ABTS radical scavenging effect $(\%)=[(\mathrm{OD}$ of Control $-\mathrm{OD}$ of Aswagandharishtam $) /(\mathrm{OD}$ of Control $) \times 100$

\section{RESULTS}

Table 1 shows the reducing power assay results. Table 2 shows the DDPH assay results and Table 3 shows the ABTS assay results. Ascorbic acid was used as a standard to compare the antioxidant activities of different assays as shown in Table 4. The comparative percentage inhibition of the three assays as compared to ascorbic acid is summarized in Fig. 1. The comparative $\mathrm{IC}_{50}$ values (Fig. 2) indicate that Aswagandharishtam exhibits excellent antioxidant capacity for all the three assays conducted and this could be a very important factor for the medicinal role of Aswagandharishtam.

\section{Reducing power assay}

The reducing power assay of Aswagandharishtam indicated good antioxidant properties as seen by its IC $_{50}$ value as compared with that of ascorbic acid being shown in Fig. 1.

\section{DDPH assay}

The DPPH assay of Aswagandharishtam also indicated good antioxidant properties as seen by its $\mathrm{IC}_{50}$ value as compared with that of ascorbic acid being shown in Fig. 1.

\section{ABTS assay}

The ABTS assay of Aswagandharishtam also indicated good antioxidant properties as seen by its $\mathrm{IC}_{50}$ value as compared with that of ascorbic acid being shown in Fig. 1.

\section{Ascorbic acid}

Ascorbic acid was used as a standard to compare the antioxidant activities of different assays as shown in Table 4

\section{DISCUSSION}

The present work was in continuation of our studies on the gas chromatography-mass spectrometry (GC-MS) and antioxidant profiles of various Ayurvedic medicines. Two more Aristaas, studied by us, namely Ashokarishtam and Partharishtam, also indicated strong antioxidant properties as was understood by the biomolecules present as shown in the GC-MS analysis [34-36].

The GC-MS analysis study of a similar medicine, Ajaswagandhadi lehyam, in which the major component is Aswagandha (Winter cherry/Indian Ginseng (root) - W. somnifera). Withania is reported to medicinal values such as immunomodulator, aphrodisiac, antitumor, anti-inflammatory, anti-stress, antioxidant, sleep-inducing, effective in memory-related conditions, insomnia, hemopoietic effect on CNS, and cardiopulmonary systems [37]. The phytoconstituents present in this plant such as Withanoside IV or VI produced dendritic outgrowth in normal cortical neurons of isolated rat cells, whereas axonal outgrowth was observed in the treatment with withanolide A in normal cortical

Table 1: The reducing power assay results of Aswagandharishtam

\begin{tabular}{|c|c|c|c|c|}
\hline S. No & Concentration $(\mu \mathrm{g} / \mathrm{ml})$ & Absorbance & $\%$ Inhibition & IC $_{50}$ \\
\hline 1 & 5 & 0.507 & 0.507 & \\
\hline 2 & 10 & 0.528 & 0.528 & \\
\hline 3 & 20 & 0.545 & 0.545 & \\
\hline 4 & 50 & 0.58 & 0.58 & \\
\hline \multirow[t]{2}{*}{5} & 100 & 0.623 & 0.623 & \\
\hline & Control & 0.475 & & \\
\hline $\mathrm{n}$ & & & 5 & \\
\hline Mean \pm SD & & & $0.5566 \pm 0.045741666$ & 250.142 \\
\hline
\end{tabular}

SD: Standard deviation 
Table 2: The DPPH assay results of Aswagandharishtam

\begin{tabular}{|c|c|c|c|c|}
\hline S. No & Concentration $(\mu \mathrm{g} / \mathrm{ml})$ & $\%$ Absorbance & Inhibition & $\mathrm{IC}_{50}$ \\
\hline 1 & 5 & 0.737 & 17.65 & \\
\hline 2 & 10 & 0.681 & 23.91 & \\
\hline 3 & 20 & 0.638 & 28.72 & \\
\hline 4 & 50 & 0.533 & 40.45 & \\
\hline \multirow[t]{2}{*}{5} & 100 & 0.482 & 46.14 & \\
\hline & Control & 0.895 & & \\
\hline $\mathrm{n}$ & & & 5 & \\
\hline Mean \pm SD & & & $31.373 \pm 11.74214333$ & 103.607 \\
\hline
\end{tabular}

DPPH: 2,2-Diphenyl-1-picrylhydrazyl, SD: Standard deviation

Table 3: The ABTS assay results of Aswagandharishtam

\begin{tabular}{|c|c|c|c|c|}
\hline S. No & Concentration $(\mu \mathrm{g} / \mathrm{ml})$ & \% Absorbance & Inhibition & $\mathrm{IC}_{50}$ \\
\hline 1 & 5 & 0.579 & 12.27 & \\
\hline 2 & 10 & 0.498 & 24.55 & \\
\hline 3 & 20 & 0.485 & 26.52 & \\
\hline 4 & 50 & 0.461 & 30.15 & \\
\hline \multirow[t]{2}{*}{5} & 100 & 0.443 & 32.88 & \\
\hline & Control & 0.666 & & \\
\hline $\mathrm{n}$ & & & 5 & \\
\hline Mean \pm SD & & & $25.274 \pm 7.949957862$ & 197.79 \\
\hline
\end{tabular}

ABTS: 2,2'-Azino-bis (3-ethylbenzothiazoline-6-sulfonic acid. SD: Standard deviation

Table 4: The ascorbic acid antioxidant profile

\begin{tabular}{llll}
\hline S. No & Concentration $(\boldsymbol{\mu g} / \mathbf{m l})$ & \% Absorbance & Inhibition \\
\hline 1 & 5 & 0.676 & 24.47 \\
2 & 10 & 0.474 & 47.04 \\
3 & 20 & 0.33 & 63.13 \\
4 & 50 & 0.212 & 76.31 \\
5 & 100 & 0.179 & 80 \\
$\mathrm{n}$ & Control & 0.895 & 5 \\
Mean \pm SD & & & $58.19 \pm 22.85702846$ \\
\hline
\end{tabular}

SD: Standard deviation

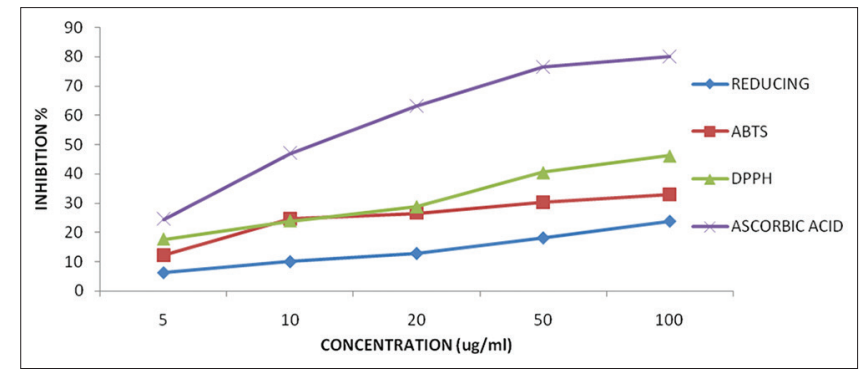

Fig. 1: The comparative inhibition percentages of all the three assays as compared to ascorbic acid (standard)

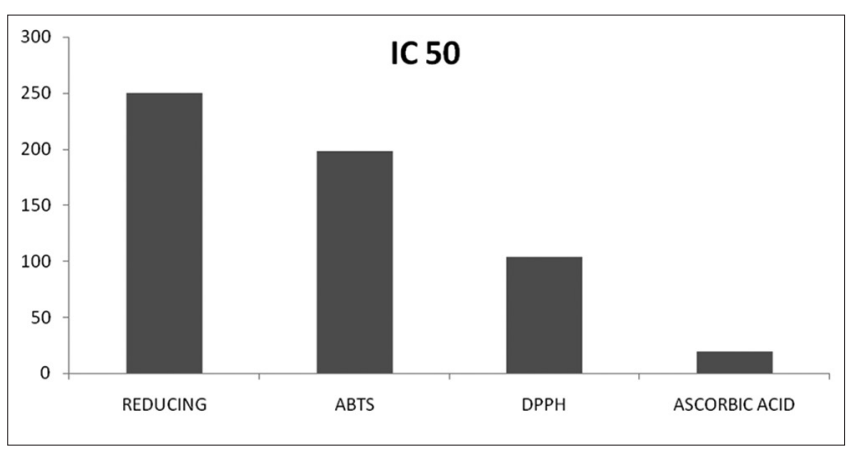

Fig. 2: The $\mathrm{IC}_{50}$ value comparison of all the three assays as compared to ascorbic acid (standard) neurons [38]. The crude extract of the plant containing the steroidal substances sitoindosides VII-X and withaferin A augmented learning acquisition and memory in both young and old rats [39].

The present medicine in study, i.e. Aswagandharistam also contains Aswagandha as a major component. Among the constituents of Aswagandharishtam, some have been reported to have strong antioxidant potentials such as C. tuberosum (Baker), $R$. cordifolia, T. chebula, B. aistata, G. glabra, P. tuberose, Operculina turpethum, $H$. indicus, P. santalinus, Z. officinalis, P. longum, P. nigrum, C. tamala, and M. ferrea L [40-56]. Thus, the antioxidant properties as shown in this present work augur well with similar activities of the majority of its constituents.

\section{CONCLUSION}

From the above discussion, it is clear that aristaas, in general, have antioxidant properties and Aswgandharishtam shows very good antioxidant activities with respect to all the three assays, namely reducing assay, DPPH assay, and ABTS assay, proving its efficacy as a potent medicine.

\section{ACKNOWLEDGMENTS}

The authors wish to acknowledge with gratitude to all those who have directly or indirectly helped in the present study.

\section{AUTHORS' CONTRIBUTIONS}

The planning and guidance for this work was done by M.R.K. Rao and K. Prabhu. The experiment was conducted by M. Kotteswari and Siva 
Kumar. Sampad Shil was involved in preparing the graphs and analysis of results. All the authors have approved the article.

\section{CONFLICTS OF INTEREST}

The authors declare that no conflict of interest exists among them.

\section{REFERENCES}

1. Shankari C, Venkatesan V, Rao MR, Saravanan K, Prabhu K, Prakash S. The GC MS analysis study of one ayurvedic medicine "Ajaswagandhadi lehyam". Int J Pharm Sci Rev Res 2016;40:33-7.

2. Queen ZE, Rao MR, Anthony J, Prabhu K, Johnson WM, Balasubramanian BS, et al. The GC MS study of one ayurvedic preparation Amrithamehari Churnam. Int J Pharm Sci Rev Res 2016;39:169-72

3. Jessica A, Rao MR, Anthony J, Prabhu K, Johnson WM, Balasubramanian BS, et al. The GC-MS study of one ayurvedic preparation Katakakhadiradi Kashayam. Int J Pharm Sci Rev Res 2016;39:216-24.

4. Rao MR, Mohammad H, Narayanan S, Prabhu K, Kalaiselvi VS, Ravi A, et al. Antioxidant assay and GC-MS analysis of one Sidha medicine Swasa Kudori tablets. Int J Pharm Sci Rev Res 2016;37:19-25.

5. Sivakumaran G, Rao MR, Prabhu K, Kalaiselvi VS, Jones S, Johnson WM, et al. Preliminary GC-MS anlaysis and antioxidant study of one ayurvedic medicine "Manasa Mitra Vatakam". Int J Pharm Sci Rev Res 2016;37:190-9

6. Lenin S, Rao MR, Prabhu K, Bindu R, Elizabeth AA, Dinakar S. The study of antioxidant activities of an Ayurvedic medicine Ayaskriti. Pharm Lett 2016;8:203-11

7. Sharada NS, Rao MR, Priya M, Prabbu K, Kalaivani KV, Kumaran D, et al. The study of antioxidant activities of an Ayurvedic medicine Kulathadi Kashayam. Pharm Lett 2016;8:245-8.

8. Rao MR, Ravi A, Narayanan S, Prabhu SK, Kalaiselvi VS, Dinakar S, et al. Antioxidant Study and GC MS analysis of an ayurvedic medicine 'talisapatradi choornam'. Int J Pharm Sci Rev Res 2016;36:158-66.

9. Rao MR, Phillips S, Kumar MH, Saranya Y, Divya D, Prabhu K. GC MS analysis, antimicrobial, antioxidant activity of an ayurvedic medicine, salmali niryasa. J Chem Pharm Res 2015;7:131-9.

10. Chandrasekar T, Rao MR, Kumar RV, Prabhu K, Kumar SN, Divya D. GC-MS analysis, antimicrobial, antioxidant activity of an ayurvedic medicine, nimbapatradi choornam. J Chem Pharm Res 2015;7:124-36.

11. Phillips S, Rao MR, Prabhu K, Priya M, Kalaivani S, Ravi A, et al. Preliminary GC-MS analysis of an ayurvedic medicine "kulathadi kashayam." J Chem Pharm Res 2015;7:393-401.

12. Rao MR, Kumar SN, Jones S, Elizabeth AA, Prabhu K, Ravi A, et al. Phytochemical and GC MS analysis of an ayurvedic formulation, patolakaturohinyadi kwatham. Int J Pharm Sci Rev Res 2015;34:6-12.

13. Ravi A, Mohammad H, Rao MR, Prabhu K, Babu H, Shridhar. Antibacterial, antioxidant activity and GC MS analysis of a sidha medicine "neerkovai tablets". Int Journ Pharm Tech 2015;7:10091-112.

14. Rao MR, Kumar MH, Amutha A, Prabhu K, Chatterjee B, Kumar SS. Phytochemical analysis and antioxidant efficacy of the resin of Bombax ceiba (Salmali). Int J Pharm Sci Rev Res 2015;30:335-9.

15. Rao MR, Ganesan A, Rengasundari G, Kumar MS, Jha NK. Treatment of peptic ulcer in animal model by Sirucinni Uppu (Herbal salt of Acalypha fruticosa Forssk.). Pharm Lett 2014;6:20-6.

16. Rao MR, Ganesan A, Rengasundari G, Kumar MS, Jha NK. The clinical efficacy of 'Kodasuri veeravaippu' (a sidhha formulation) in patients affected by the disease "Keelvayu" (Arthritis). Pharm Lett 2014;6:71-7.

17. Rao MR, Ganesan A, Rengasundari G, Kumar MS. The curative role of Acalypha fruticosa Forrssk. (Sirucinni uppu) salt on peptic ulcer patients. Pharm Lett 2014;6:44-51.

18. Velpandian V, Anbu N, Selangovan S, Musthafa MM. Antihypertensive activity of Ardostachys jatamansi in hypertensive rats following renal gold blatt occlusion method. World J Pharm Res 2014;3:769-77.

19. Parekar RR, Jadhav KS, Marathe PA, Rege NN. Effect of Saraswatarishta in animal models of behavior despair. J Ayurveda Integr Med 2014;5:141-7.

20. Sandhiya S, Kumar MP, Velpandian V, Thenmozhi P, Banumathi V. Standardization of Siddha polyherbal formulation vaeppampoovathy mathirai. Am J Pharm and Health Res 2014;10:129-37.

21. Rao MR, Ganesan A, Rengasundari G, Kumar MS, Jha NK. 'Kodasuri veeravaippu' a sidha preparation, against carrageenan induced paw edema and cotton pellet induced granuloma in albino rats. Pharm Lett 2013;5:99-104

22. Kumar MS, Rao MR, Ganesan A, Rengasundari G. Antibacterial screening of kodasuri veeravaippu, a siddha salt preparation. Int J Pharm Sci Rev Res 2013;20:140-1.

23. Velpandian V, Kumar MP, Gnanavel IS, Anbu N, Khader AM. Clinical evaluation of kodipavala chunnam in the treatment of Infective hepatitis, drug induced hepatitis and alchoholic hepatitis. Int Res J Pharm 2013;4:152-7.

24. Kanimozhi B, Arumugam K, Velpandian V, Kumar MP. Diuretic activity of siddha formulation ashta gunma triaavagam in rat. Int J Pharm Phytopharm Res 2013;2:340-3.

25. Gupta K, Ashok BK, Ravishankar B, Thakar AB. Anti-anxiety and antidepressant activities of sarasvata choorna in experimental animals. Ayu 2011;32:590-3.

26. Pandey N, Chaurasia JK, Tiwari OP, Tripathi YB. Antioxidant properties of different fractions of tubers from Pueraria tuberosa Linn. Food Chem 2007;105:19-22.

27. Govindarajan R, Vijayakumar M, Pushpangadan P. Antioxidant approach to disease management and the role of rasayana herbs of ayurveda. J Ethnopharmacol 2005:99:165-78

28. Balakrishnan BB, Krishnasamy K. Evaluation of free radical screening and antioxidant potential of Moringa concanensis nimmo-a medicinal plant used in Indian traditional medication system. Int J Pharm Pharm Sci 2018;10:91-7.

29. Tambewagh UU, Rojatkar SR. In vitro antioxidant and in vivo antiinflammatory activity of the aerial part of Blumea eriantha DC. Int J Pharm Pharm Sci 2018; 10:75-9.

30. Bihani GV, Rojatkar SR, Bodhankar SL. Investigation of in vivo analgesic and anti-inflammatory activity in rodents and in vitro antioxidant activity of extracts of whole plant of Cyathocline purpurea. Int J Pharm Pharm Sci 2014;6:492-8.

31. Arulpriya P, Lalitha P, Hemalatha S. In vitro antioxidant testing of the extracts of Samanea saman (Jacq.) Merr. Chem Sinica 2010;1:73-9.

32. Oyedemi SO, Afolayan AJ. In vitro and in vivo antioxidant activity of aqueous extracts of Leonotis leonurus. Int J Pharmacol 2011;7:248-56

33. Fan H, Yang GZ, Zheng T, Mei ZN, Liu XM, Chen Y, et al. Chemical constituents with free-radical-scavenging activities from the stem of Microcos paniculata. Molecules 2010;15:5547-60.

34. Ravi A, Prabhu SP, Rao MR, Prabhu K, Kalaiselvi VS, Saranya Y. Identification of Active Biomolecules in saraswatarishtam (an ayurvedic preparation) by GC-MS analysis. Int J Pharm Sci Rev Res 2015;33:58-62.

35. Ravi A, Gupta M, Rao MR, Kalaiselvi VS, Prabhu K, Dinakar S, et al. GC MS analysis of an ayurvedic medicine "ashokarishtam". Pharm Lett $2015 ; 7: 45-52$

36. Sadhanandham S, Narayanan G, Rao MR, Prabhu K, Jones S, Ravi A, et al. GC-MS analysis and antioxidant studies of an ayurvedic drug, partharishtam. Int J Pharm Sci Rev Res 2015;34:273-81.

37. Uddin Q, Samiulla L, Singh VK, Jamil SS. Phytochemical and pharmacological profile of Withania somnifera Dunal: A review. J Appl Pharm Sci 2012;2:170-5.

38. Tohda C, Kuboyama T, Komatsu K. Search for natural products related to regeneration of the neuronal network. Neurosignals 2005;14:34-45.

39. Ghosal S, Lal J, Srivastava R, Bhattacharya SK, Upadhyay SN, Jaiswal AK, et al. Immunomodulatory and CNS effects of sitoindosides IX and $\mathrm{X}$, two new glycowithanolides from Withania somnifera. Phytother Res 1989;3:201-6.

40. Patil VN, Deokule SS. Pharmacognostic study of Chlorophytum tuberosum Baker. Int J Ayurveda Res 2010;1:237-42.

41. Mariselvam R, Ranjitsingh AJ, Nanthini AU. Preparation and characterization of silver nanoparticles using Rubia cordifolia plant root extract and their microbial properties. Int J Adv Res 2013;1:56-61.

42. Gorle AM, Patil SS. Evaluation of antioxidant and antiacne property of Rubia cordifolia. Pharm Sinica 2013;1:59-63.

43. Lodia S, Kansala L. Antioxidant activity of Rubia cordifolia against lead toxicity. Int J Pharm Sci Res 2012;3:2224-32.

44. Bag A, Bhattacharya SK, Chattopadhyay RR. The development of Terminalia chebula Retz. (Combretaceae) in clinical research. Asian Pac J Trop Biomed 2013;3:244-52.

45. Sharma K, Bairwa R, Chauhan N, Srivastava B, Saini NK. Berberis aristata: A review. Int J Res Ayurveda Pharm 2011;2:383-8.

46. Damle M. Glycyrrhiza glabra (Liquorice) - A potent medicinal herb. Int J Herb Med 2014;2:132-6.

47. Pandey N, Yadav D, Pandey V, Tripathi YB. Anti-inflammatory effect of Pueraria tuberosa extracts through improvement in activity of red blood cell anti-oxidant enzymes. Ayu 2013;3:297-301.

48. Kumar SV, Sujatha C, Shymala J, Nagasudha B, Mishra SH. Protective effect of root extract of Operculina terpethum Linn. against paracetamol induced hepatotoxicity in rats. Indian J Pharm Sci 2006;68:32-5. 
49. Anbuselvam C, Vijayavel K, Balsubramaniyan MP. Protective effect of Operculina turpethum against 7, 12 dimethylbenz (a)anthracene induced oxidative stress with reference to breast cancer in experimental rats. Chem Biol Interact 2007;168:229-36.

50. Chatterjee S, Banerjee A, Chandra I. Hemidesmus indicus: A rich source of herbal medicine. Med Aromat Plants 2014;3:e155.

51. Azamthulla M, Balasubramanian R, Kavimani S. A review on Pterocarpus santalinus linn. World J Pharm Res 2015;4:282-92.

52. Adel PR, Prakash J. Chemical composition and antioxidant properties of ginger root (Zingiber officinalis). J Med Plants Res 2010;4:2674-9.

53. Kumar S, Kamboj J, Suman, Sharma S. Overview for various aspects of the health benefits of Piper longum Linn. fruit. J Acupunct Meridian Stud 2011;4:134-40.

54. Sharma PC, Yelne MB, Dennis TJ. Database on Medicinal Plants Used in Ayurveda. Vol. 5. New Delhi: Central Council for Research in Ayurveda \& Siddha; 2002

55. Preety A, Sharma S. A brief review on Cinnamomum tamala (Buch.Ham.) Nees and Eberm.: An important medicinal tree. Int J Res Biol Sci 2016;6:26-31

56. Jayanthi G, Kamalraj S, Karthikeyan K, Muthumary J. Antimicrobial and antioxidant activity of the endophytic fungus Phomopsis sp. GJJM07 isolated from Mesua ferrea. Int J Curr Sci 2011;1:85-90. 